\title{
Inventory of Organic Carbon in a Pterogyne nitens Tul. Plantation in Southwest Bahia, Brazil
}

\author{
Patrícia Anjos Bittencourt Barreto-Garcia ${ }^{1}$ (D), Priscila Silva Matos ${ }^{2}$ (D), \\ Carlos Roberto Sanquetta ${ }^{3}$ (D), Paulo Henrique Marques Monroe ${ }^{1}$ (i) \\ ${ }^{1}$ Universidade Estadual do Sudoeste da Bahia (UESB), Vitória da Conquista, BA, Brasil \\ ${ }^{2}$ Universidade Federal Rural do Rio de Janeiro (UFRRJ), Seropédica, RJ, Brasil \\ ${ }^{3}$ Universidade Federal do Paraná (UFPR), Curitiba, PR, Brasil
}

\begin{abstract}
Carbon binding capacity varies between forest plantations, mainly in terms of species and climate and soil conditions. The objective of this study was to estimate the amount of organic carbon stored in aerial tree biomass in the litter and soil of a homogeneous planting of Pterogyne nitens Tul. located in the Southwest Bahia region of Brazil. The woody biomass was obtained by destructive method. Litter collection was carried out using a wooden template $\left(0.25 \mathrm{~m}^{2}\right)$. Soil samples were collected at four depths $(0-5,5-10,10-20$ and 20-40 cm). The carbon stored in all studied compartments totaled $47.1 \mathrm{Mg} \mathrm{ha}^{-1}$ with a greater contribution from the ground $\left(31.4 \mathrm{t} \mathrm{ha}^{-1}\right)$. The accumulated litter was the lowest carbon compartment, storing about $1.4 \%$ of the total. Among the different fractions of the biomass, the stem is the largest carbon reservoir, representing about $46 \%$ of fixed $C$ biomass.
\end{abstract}

Keywords: arboreal biomass, litter, soil, carbon dioxide, native species. 


\section{INTRODUCTION}

Carbon dioxide $\left(\mathrm{CO}_{2}\right)$ concentration in the atmosphere has increased over the years, changing from 280 ppmv in 1750 to $367 \mathrm{ppmv}$ in 1999 (Lal, 2004), and reaching the order of 390 ppmv nowadays (Pachauri \& Meyer, 2014). $\mathrm{CO}_{2}$ is considered the most relevant among greenhouse gases due to the increase in its concentration in the atmosphere. Among the alternatives to reduce atmospheric emissions of $\mathrm{CO}_{2}$, to decrease burning of fossil fuels and deforestation for establishing low productivity farming systems may be highlighted, in addition to promoting large-scale reforestation (Watzlawick et al., 2012).

The forest ecosystem can be a source of replenishing carbon (C) into the atmosphere due to reduced productivity, increased mortality rates and soil exposure as a consequence of anthropic or natural actions such as the use of fire and conventional techniques of soil preparation, suppression of native vegetation, and climate change, among others. On the other hand, it can also contribute to $\mathrm{C}$ draining, especially during soil repopulation with forest plantations (Hosokawa et al., 1998). These plantations have great capacity to fix $\mathrm{CO}_{2}$ in the atmosphere, and for this reason are considered an important strategy for long term $\mathrm{C}$ storage in plant biomass, as well as in litter and soil, which constitute reservoirs and potential atmospheric $\mathrm{CO}_{2}$ sinks (Castro, 1996).

Carbon fixation capacity is highly variable among forest plantations, mainly in relation to the planted species and climate and soil conditions (Masera et al., 2003). Several studies related to the quantification of biomass and carbon stocks have been developed in Brazil, both in native forests (Caldeira et al., 2004; Chambers et al., 2001; Higuchi et al., 2004; Morais et al., 2013; Nelson et al., 1999; Sallis et al., 2006; Scolforo et al., 2016; Silva et al., 2015) and in planted forests of exotic species, mainly of the genera Eucalyptus and Pinus (Balbinot et al., 2003; Barreto et al., 2014; Dalla-Corte \& Sanquetta, 2007; Faria et al., 2008; Gatto et al., 2010; Lima et al., 2016; Watzlawick et al., 2013). However, the number of studies that quantify C-fixation capacity in forest plantations of native species is still limited (Caldeira et al., 2003; GamaRodrigues et al., 2008; Thompson, 2009; Watzlawick et al., 2003), in particular under the conditions of the Northeast region of the country.
Among the native species that present potential for use in reforestation programs in the Northeast region of Brazil, the Pterogyne nitens Tul., also popularly known as madeira-nova and amendoimbravo, stands out for generating wood with economic value for diverse purposes, as it has fast growth and adapts well to the region's environmental conditions (Lorenzi, 1998). Such adaptation is attributed to its ease of establishment in soils which are poor in nutrients and organic matter, due to its ability to fix nitrogen by symbiosis with diazotrophic bacteria and mycorrhizal fungi (Franco et al., 1995). Despite the proven importance of this species, little is known about its ability to fix carbon. In a study carried out in a homogeneous plantation of Pterogyne nitens at 6 years of age, Fraga et al. (2014) reported a wood volume of approximately $51 \mathrm{~m}^{3}$ per hectare, which is an indicative of its biomass accumulation potential, and consequently of $\mathrm{C}$ storage.

Given this context, the objective of this study was to estimate the amount and distribution of organic $\mathrm{C}$ stored in aerial biomass components, litter and soil of a homogeneous 6-year-old plantation of P. nitens.

\section{MATERIALS AND METHODS}

\subsection{Study area characterization}

This study was carried out in a homogeneous 6-year-old plantation of Pterogyne nitens Tul. located in the experimental area of the Universidade Estadual do Sudoeste da Bahia (Uesb), municipality of Vitória da Conquista, BA, Brazil. The plantation was established according to $3 \mathrm{~m} \times 3 \mathrm{~m}$ spacing, with seminal seedlings and fertilization located in the pit (100 $\mathrm{g}$ of simple superphosphate). Soil preparation consisted of trenching and opening the pits. Weeding the lines and between the lines was carried out for controlling spontaneous weeds at two, six and 12 months after planting.

The region has flat to slightly undulating relief (average altitude of $840 \mathrm{~m}$ ). The climate is subtropical highland (Cwb) according to Köppen's classification with average temperature and annual rainfall of $25^{\circ} \mathrm{C}$ and $850 \mathrm{~mm}$, respectively. The predominant vegetation in the region is classified as SemiDeciduous Seasonal Forest Montana, known regionally as Liana Forest. The soil of the studied 
Table 1. Chemical and granulometric composition of soil under a homogeneous Pterogyne nitens plantation in Southwest Bahia, Brazil.

\begin{tabular}{|c|c|c|c|c|c|c|c|c|c|c|}
\hline Depth & Clay & Silt & Sand & pH & $\mathbf{N}$ & $\mathbf{P}$ & K & $\mathrm{Ca}$ & $\mathbf{M g}$ & $\mathrm{H}+\mathrm{Al}$ \\
\hline $\mathrm{cm}$ & \multicolumn{4}{|c|}{------ $\mathrm{g} \mathrm{kg}^{-1}$------ } & $\mathrm{g} \mathrm{kg}^{-1}$ & \multicolumn{2}{|c|}{---- mg kg ${ }^{-1}$--- } & \multicolumn{3}{|c|}{----- $\mathrm{cmol}_{\mathrm{c}} \mathrm{kg}^{-1}$----- } \\
\hline $0-5$ & 608 & 12 & 380 & 5.57 & 1.78 & 1.39 & 83.82 & 1.24 & 1.14 & 2.86 \\
\hline 5-10 & 547 & 33 & 387 & 5.25 & 1.31 & 1.23 & 44.25 & 0.97 & 0.83 & 3.05 \\
\hline $10-20$ & 575 & 60 & 365 & 5.58 & 1.19 & 1.33 & 22.36 & 1.01 & 0.75 & 3.11 \\
\hline $20-40$ & 530 & 35 & 435 & 5.25 & 0.93 & 1.26 & 12.42 & 0.78 & 0.61 & 2.91 \\
\hline
\end{tabular}

Analysis performed according to Embrapa (1997): $\mathrm{pH}$ (water); $\mathrm{P}$ and K extractable by Mehlich-1; Ca, $\mathrm{Mg}$ and $\mathrm{Al}$ exchangeable by KCl 1 mol L ${ }^{-1}$.

area is classified as Dystrophic Yellow Latosol (Santos et al., 2006), with a texture ranging from very clayey to clayey (Table 1). Table 1 presents the chemical and granulometric characterization of the soil at depth of $0-40 \mathrm{~cm}$.

\subsection{Biomass and carbon}

Biomass and C stock quantification were performed in three compartments of the ecosystem: tree biomass, litter and soil.

In order to obtain the diametrical distribution of the trees, the stem diameter at the height of $1.30 \mathrm{~m}$ from the soil level (DBH) of all individuals of the stand was measured. Because the species present predominantly more than one stem, the $\mathrm{DBH}$ of all stems originating up to $1.30 \mathrm{~m}$ were included. The $\mathrm{DBH}$ measurements of the stems were grouped into six classes considering an amplitude of $2.1 \mathrm{~cm}$, corresponding to the standard deviation of the obtained DBH measurements.

Eighteen trees were selected for quantifying tree biomass with representative stems from all diametric classes, totaling 54 sampled stems. The number of sampled trees was based on referenced literature studies, which adopted a sample number between 10 and 35 trees (Caldeira et al., 2011; Melo et al., 2014; Moura et al., 2006; Saidelles et al., 2009; Sanquetta et al., 2003; Vieira et al., 2009).

After felling, the sample trees were fractionated considering the simple separation method (Sanquetta et al., 2004). While still in the field, each tree component (leaves, branches and stem with the bark) was weighed using a mechanical scale with a capacity of $150 \mathrm{~kg}$ and a precision of $50 \mathrm{~g}$ to obtain the fresh biomass of each individual per compartment. After weighing, samples of about $300 \mathrm{~g}$ were taken from each tree compartment and taken to the laboratory where they were weighed and kept in a forced circulation drying oven at $60^{\circ} \mathrm{C}$ until the stabilization of its dry mass was complete.

The dry biomass of the tree components was estimated by multiplying the wet biomass by the conversion factor (ratio between dry and wet mass of the samples). Thus, the total dry biomass of each tree was obtained by the sum of the dry biomass of all measured compartments. In turn, the total biomass per hectare of each component was calculated by multiplying the mean value of the trees by the estimated number of trees per hectare at 6 years of age ( 1,000 trees), taking into account the initial planting mortality.

Carbon content of the tree components' biomass samples was determined using a Leco C-144 carbon analyzer at the Center for Excellence in Research on Biomass Carbon Fixation (Biofix) of the Universidade Federal do Paraná (UFPR). Carbon stocks per tree $(\mathrm{kg})$ and area $\left(\mathrm{Mg} \mathrm{ha}^{-1}\right)$ were estimated based on the dry biomass values of the trees and their respective C contents.

For soil sample collection, four plots of $21 \mathrm{~m} \times 21 \mathrm{~m}$ dimensions were established, which were randomly distributed within the plantation area. The sampling was performed at four depths $(0-5,5-10,10-20$ and 20-40 cm). Four trenches of $0.4 \mathrm{~m} \times 0.4 \mathrm{~m}$ were randomly opened in each plot from which simple samples were collected and then gathered to form a composite sample of each depth. In addition, an undeformed sample was also taken by depth using a volumetric ring to determine soil density.

For the sampling of accumulated litter on the soil surface, 20 plots of $15 \mathrm{~m} \times 15 \mathrm{~m}$ were demarcated according to a random walk through the stand. Collection was carried out in each plot with the aid of a wooden 
mold in $0.25 \mathrm{~m}^{2}$ of useful area $(0.5 \mathrm{~m} \times 0.5 \mathrm{~m})$ which was randomly cast onto the soil with three repetitions that were then pooled to form a composite sample. The material circumscribed by the mold was carefully removed, avoiding collection of soil and live roots. All deciduous plant material deposited on the soil at different degrees of decomposition was considered litter. After collection, the sampled material was screened (five fractions were separated: leaves, branches, bark, reproductive structures and amorphous material), dried in a forced ventilation oven (at $60{ }^{\circ} \mathrm{C}$ until constant weight), weighed on a precision scale $(0.01 \mathrm{~g})$ and milled to the consistency of powder using a sixknife mill and metal sieves. The dry mass results (g) of the sum of the three samples from each plot were converted to $\mathrm{Mg} \mathrm{ha}^{-1}$.

The determination of organic $\mathrm{C}$ from soil and litter was carried out by oxidation in acid medium using $\mathrm{Na}_{2} \mathrm{Cr}_{2} \mathrm{O}_{7} 4 \mathrm{~N}$ (Embrapa, 1997) and $\mathrm{K}_{2} \mathrm{Cr}_{2} \mathrm{O}_{7} 4 \mathrm{~N}$ (Anderson \& Ingram, 1996), respectively. Soil density was calculated based on the Kopecky ring method (Embrapa, 1997).

Carbon stocks at each soil depth were estimated according to the equation $\mathrm{CS}=\mathrm{C} \times \mathrm{Sd} \times \mathrm{Tck} \times 10$, in which CS represents $\mathrm{C}$ stock in $\mathrm{Mg} \mathrm{ha}^{-1}$; $\mathrm{C}$, the content of this element in $\mathrm{g} \mathrm{kg}^{-1}$; $\mathrm{Sd}$, soil density in $\mathrm{kg} \mathrm{dm}^{3}$; and Tck, the thickness of the layer under analysis in meters. To verify trends of $C$ increase or reduction in different soil depths, and considering that the analyzed layers presented variable thickness, an estimate of stored $\mathrm{C}$ per centimeter of depth was performed $\left(\mathrm{Mg} \mathrm{ha}^{-1} \mathrm{~cm}^{-1}\right)$ by dividing the $\mathrm{C}$ stock by the thickness $(\mathrm{cm})$ of each layer, as adopted from Barreto et al. (2011).

\section{RESULTS AND DISCUSSION}

\subsection{Diameter distribution}

The studied stand had trees with a minimum diameter of $1.8 \mathrm{~cm}$ and a maximum of $13.6 \mathrm{~cm}$. The frequency distribution of the individuals by grouping into six diametric classes with amplitude of $2.1 \mathrm{~cm}$ corresponded to normal distribution according to the Shapiro-Wilk normality test, with a higher concentration of individuals in more central classes (of 4.2 and $6.3 \mathrm{~cm}$ ) (Figure 1), a characteristic pattern of even-aged forest stands (Machado \& Figueiredo Filho, 2003).

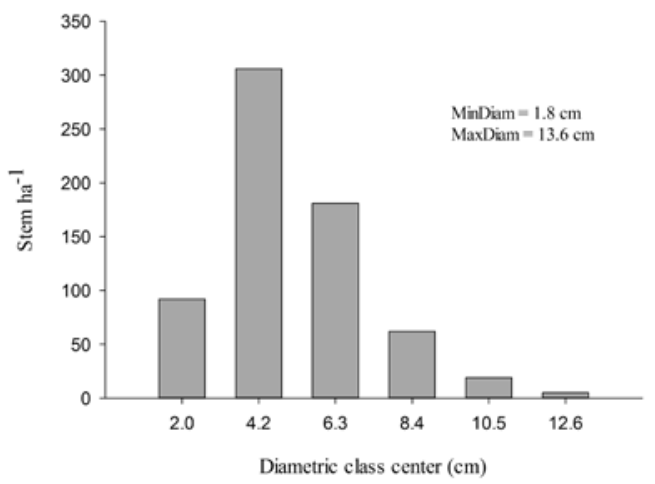

Figure 1. Diametric distribution of stems in a homogeneous Pterogyne nitens plantation.

\subsection{Organic carbon in aerial biomass}

The $\mathrm{C}$ stock of tree biomass in all components totaled approximately $15.0 \mathrm{Mg} \mathrm{ha}^{-1}$ (Table 2). The component with the highest participation was the stem, with 7.2 $\mathrm{Mg} \mathrm{ha}^{-1}$, which represented about $46 \%$ of the total C stock in the biomass. This was followed by the branches (43\%) and leaves (12\%). This same distribution sequence was observed by Caldeira et al. (2003) in a 6-year-old Acacia mearnsii stand and by Watzlawick et al. (2003) in a 30-year-old Araucaria angustifolia plantation. The contribution proximity of the tree and branch components in the total biomass composition (both with a share of over $40 \%$ ) is possibly related to the fact that the species exhibit several stems and bifurcations in virtually all stems. Therefore, this anatomical characteristic would be responsible for the high branch biomass (12.6 kg tree $\mathrm{e}^{-1}$ ).

Leaves presented the highest levels of C (48\%) among the aerial biomass components, followed by branches and stems (46\%) (Table 2). In analyzing several species of Dense Tropical “Terra Firme" Rainforest in the Amazon region, Higuchi \& Carvalho (1994) found mean $\mathrm{C}$ contents of $48 \%$ for stem and branches and 39\% for leaves. Dallagnol et al. (2011) found higher levels in Araucaria angustifolia needles (47\%) and in Populus sp. branches (45\%).

\subsection{Organic carbon in litter}

The total dry biomass of litter on the soil was $1.5 \mathrm{Mg} \mathrm{ha}^{-1}$ and it had $42 \%$ of $\mathrm{C}$ content, which corresponds to $0.7 \mathrm{Mg}$ of $\mathrm{C} \mathrm{ha}^{-1}$ (Table 3). This content is higher than 
Table 2. Dry biomass, concentrations and amounts of organic carbon components of 6-year-old Pterogyne nitens trees.

\begin{tabular}{|c|c|c|c|c|c|c|}
\hline \multirow{2}{*}{ Component } & \multicolumn{2}{|c|}{ Biomass } & \multicolumn{3}{|c|}{ Carbon } & \multirow{2}{*}{$\%$ of total carbon } \\
\hline & kg tree ${ }^{-1}$ & $\operatorname{Mg~ha}^{-1}$ & $\%$ & kg tree ${ }^{-1}$ & $\operatorname{Mg~ha}^{-1}$ & \\
\hline Leaves & $3.24(0.64)$ & 3.60 & 48.46 & $1.57(0.31)$ & 1.74 & 11.59 \\
\hline Branches & $12.57(2.6)$ & 13.97 & 46.06 & $5.79(1.18)$ & 6.43 & 42.84 \\
\hline Stems & $13.37(1.5)$ & 14.85 & 46.07 & $6.16(0.70)$ & 6.84 & 45.57 \\
\hline Total & 29.18 & 32.42 & & 13.52 & 15.01 & 100.00 \\
\hline
\end{tabular}

$\%$ : carbon concentration; \% of total carbon: proportion of total carbon fixed in tree biomass; values in parentheses refer to the mean standard error $(\mathrm{n}=18)$.

that indicated by the Intergovernmental Panel on Climate Change (Eggleston et al., 2006), which suggests 37\% for the litter. Torres et al. (2013) observed an average of $52 \%$ of $\mathrm{C}$ content in the litter in a Semi-Deciduous Seasonal Forest in Minas Gerais. On the other hand, Higuchi \& Carvalho (1994), in a Tropical Forest in the Amazon Region, and Morais et al. (2017), in the Cerrado vegetation of the state of Minas Gerais, found mean C contents in the litter of $39 \%$ and $44 \%$, respectively.

The amount of $\mathrm{C}$ stored in the litter found in the present study (Table 3) was similar to the amount found by Gama-Rodrigues et al. (2008) in Claraíba stands (Cordia trichotoma (Vell.) Arrab.) in the Southeast of Bahia at 22 years of age (1.4 Mg of $\left.\mathrm{C} \mathrm{ha}^{-1}\right)$. However, higher values have been reported in other studies, such as those by Watzlawick et al. (2002) in a Mixed Ombrophilous Forest Montana in Paraná (2.90 $\mathrm{Mg} \mathrm{ha}^{-1)}$, and by Schneider et al. (2005) in 4-year-old A. mearnsii stands in Rio Grande do Sul (2.26 $\left.\mathrm{Mg} \mathrm{ha}^{-1}\right)$.

The fraction that most contributed to the total litter composition were the branches (Table 3), which can be attributed to the fact that these components are made of woody materials which are more resistant to decomposition than non-lignified leaves and tender branches (Swift et al., 1979). These results contrast with those found by Schumacher et al. (2004), Pires et al. (2006) and Ferreira et al. (2007), who found a greater contribution of the leaves in the accumulated litter in Araucaria, Restinga and Sabia forests, respectively. It is probable that the lower participation of the leaves in the litter composition in this study has been determined by a low $\mathrm{C} / \mathrm{N}$ ratio, and consequently a higher decomposition rate of the leaf component, since the studied species is a nitrogen fixation legume (Silva et al., 2004).

Similarly to what was observed for dry biomass, the branches component had the highest amount of $\mathrm{C}$ fixed per hectare, representing more than $60 \%$ of the carbon stored in the litter (Table 3). However, the $\mathrm{C}$ content of this component (45\%) was similar to that found in the leaves (46\%), which contributed $37 \%$ of the litter $\mathrm{C}$. The other components had small participation in the total C composition: bark $(0.5 \%)$, reproductive structures $(0.6 \%)$ and amorphous material (1.5\%).

\subsection{Organic carbon in soil}

The amount of $\mathrm{C}$ stored in soil up to $40 \mathrm{~cm}$ was 31.4 $\mathrm{Mg} \mathrm{ha}^{-1}$, with contents between 6.5 and $10.4 \mathrm{~g} \mathrm{~kg}^{-1}$ (Table 4). Caldeira et al. (2003) observed lower results for the same depth under 6-year-old A. mearnsii plantation soils in Rio Grande do Sul (19.7 $\mathrm{Mg} \mathrm{ha}^{-1}$ ). However, Balbinot et al. (2003) observed superior results (148 $\left.\mathrm{Mg} \mathrm{ha}^{-1}\right)$ in soils under 5-year-old Pinus taeda plantations.

Variations between forest stands and their capacity to store carbon in the soil can be attributed to differences in the amount and quality of litter that contributed to the soil over the years, as well as to root turnover. Thus, the $\mathrm{C}$ stock of $10.2 \mathrm{Mg} \mathrm{ha}^{-1}$ found in the $0-10 \mathrm{~cm}$ layer of soil could be a consequence of an accumulation of $1.5 \mathrm{Mg} \mathrm{ha}^{-1}$ of litter (Table 4). In soils with similar granulometric composition, a more easily decomposable litter generally results in lower $\mathrm{C}$ accumulation when compared to a more recalcitrant litter composed of more resistant substances to decomposition (Gama-Rodrigues et al., 1999).

The $\mathrm{C}$ soil stock was higher in the surface layers and decreased with increasing depths (Table 4). By adding carbon accumulations $\left(\mathrm{Mg} \mathrm{ha}^{-1}\right)$ of the first three soil layers, it can be noted that the $0-20 \mathrm{~cm}$ layer stores about $60 \%$ of the total stored in the $40 \mathrm{~cm}$ profile (Table 4), and that shows the strong influence of forest cover on $\mathrm{C}$ distribution in the soil. In evaluating the carbon stocks at $100 \mathrm{~cm}$ depth of soil under Pinus 
Table 3. Dry biomass levels and amounts of organic carbon components of accumulated plant litter in homogeneous 6-year-old Pterogyne nitens plantation.

\begin{tabular}{llccc}
\multirow{2}{*}{ Component } & $\begin{array}{c}\text { Biomass } \\
\mathbf{M g ~ h a}^{-1}\end{array}$ & $\%$ & Carbon & \% of total carbon \\
\cline { 3 - 4 } Leaves & $0.527(0.07)$ & $45.94(1.04)$ & 0.242 & 37.17 \\
Branches & $0.888(0.17)$ & $44.99(1.25)$ & 0.392 & 60.22 \\
\hline Bark & $0.007(0.01)$ & $43.48(1.09)$ & 0.003 & 0.46 \\
RS & $0.010(0.01)$ & $42.91(1.18)$ & 0.004 & 0.61 \\
AM & $0.064(0.05)$ & $30.12(1.83)$ & 0.010 & 1.54 \\
Total & 1.496 & & 0.651 & 100
\end{tabular}

$\%$ of total carbon: proportion of total carbon fixed in the litter biomass; RS: reproductive structures; AM: amorphous material. Values in parentheses refer to the standard error of the mean $(n=20)$.

Table 4. Organic $\mathrm{C}$ content $\left(\mathrm{g} \mathrm{kg}^{-1}\right)$ and stocks $\left(\mathrm{Mg} \mathrm{ha}^{-1}\right)$ from depths of 0-5, 5-10, 10-20 and 20-40 $\mathrm{cm}$ soil under homogeneous Pterogyne nitens plantation.

\begin{tabular}{|c|c|c|c|c|c|}
\hline \multirow{2}{*}{$\frac{\text { Depth }}{\mathrm{cm}}$} & \multirow{2}{*}{$\frac{\mathrm{Sd}}{\mathrm{kg} \mathrm{dm}^{-3}}$} & \multicolumn{3}{|c|}{ Carbon } & \multirow{2}{*}{$\%$ of total carbon } \\
\hline & & $\mathrm{g} \mathrm{kg}^{-1}$ & $\mathrm{Mg} \mathrm{ha}^{-1}$ & $\mathrm{Mg} \mathrm{ha}^{-1} \mathrm{~cm}^{-1}$ & \\
\hline $0-5$ & $1.11(0.01)$ & $10.40(1.37)$ & $5.77(0.69)$ & $1.04(0.14)$ & 17.22 \\
\hline $5-10$ & $1.00(0.04)$ & $8.81(1.21)$ & $4.41(0.61)$ & $0.88(0.12)$ & 14.57 \\
\hline $10-20$ & $1.06(0.04)$ & $8.29(0.14)$ & $8.79(0.14)$ & $0.83(0.01)$ & 27.46 \\
\hline $20-40$ & $1.01(0.04)$ & $6.15(1.38)$ & $12.42(1.1)$ & $0.62(0.14)$ & 40.74 \\
\hline Total & & & 31.39 & & 100.00 \\
\hline
\end{tabular}

$\%$ of total carbon: proportion of total carbon fixed at 0-40 cm depth of soil; Sd: soil density. Values in parentheses refer to the mean standard error $(\mathrm{n}=4)$.

taeda planting, Balbinot et al. (2003) found that $37 \%$ of the carbon was accumulated in the $0-20 \mathrm{~cm}$ layer.

It was also possible to observe a higher fertility level in the soil surface layer $(0-5 \mathrm{~cm})$ and a decrease in higher depths (Table 1). This distribution corroborates previously discussed results, evidencing the important contribution of the vegetation cover to improve soil characteristics, given the continuous deposition of organic residues which favors $\mathrm{C}$ storage and nutrient cycling in the most superficial layers. Similar results were found by Neves et al. (2004), Grimm et al. (2008), Qiji et al. (2008) and Neumann-Cosel et al. (2011). According to Gama-Rodrigues et al. (2008), it is common to verify the increase of the sum of bases in the superficial soil layers in tree legume plantations soon after the beginning of crop stabilization.

\subsection{Total carbon stock}

The $\mathrm{C}$ stored in all studied compartments totaled 47.1 $\mathrm{Mg} \mathrm{ha}^{-1}$, with the highest contribution from soil
(31.4 $\mathrm{Mg} \mathrm{ha}^{-1}$ ), corresponding to $66.7 \%$, followed by aerial biomass (15.0 $\left.\mathrm{Mg} \mathrm{ha}^{-1}\right)$ (31.9\%) and litter $\left(0.7 \mathrm{Mg} \mathrm{ha}^{-1}\right)(1.4 \%)$. These results confirm the premise that the soil compartment constitutes the main C sink of the atmosphere (Lal, 2004; Nair et al., 2009) and are in agreement with results reported by several studies such as by Caldeira et al. (2003) in an A. mearnsii stand in Rio Grande Sul, by Gatto et al. (2010) in Eucalyptus plantations in the Central-West region of Minas Gerais and by Gama-Rodrigues et al. (2011) in agroforestry systems in the South of Bahia, which verified $C$ stocks in the soil on the order of 101, 122 and $300 \mathrm{Mg} \mathrm{ha}^{-1}$, respectively.

\section{CONCLUSIONS}

The carbon stocked in all studied compartments totaled 47.1 $\mathrm{Mg} \mathrm{ha}^{-1}$, with greater contribution from soil (31.4 Mg ha-1 at $0-40 \mathrm{~cm}$ depth) and less from litter $\left(0.7 \mathrm{Mg} \mathrm{ha}^{-1}\right)$. The stem constitutes the largest $\mathrm{C}$ reservoir of aerial tree biomass, representing around 
$46 \%$ of total fixed C ( $\left.15.0 \mathrm{Mg} \mathrm{ha}^{-1}\right)$. A higher proportion of the total C stored in the soil up to $40 \mathrm{~cm}$ is in the 0-20 cm layer (about 60\%).

\section{SUBMISSION STATUS}

Received: 13 Aug., 2016

Accepted: 5 Dec., 2017

\section{CORRESPONDENCE TO}

\section{Patrícia Anjos Bittencourt Barreto-Garcia}

Universidade Estadual do Sudoeste da Bahia (UESB), Departamento de Engenharia Agrícola e Solos, Estrada do Bem Querer, km 4, s/n, CEP 45031-300, Vitória da Conquista, BA, Brasil e-mail: patriciabarreto@uesb.edu.br

\section{REFERENCES}

Anderson JD, Ingram JSI. Tropical soil biology and fertility: a handbook of methods. Wallingford: CAB International; 1996.

Balbinot R, Schumacher MV, Watzlawick LF, Sanquetta CR. Inventário do carbono orgânico em um plantio de Pinus taeda aos 5 anos de idade no Rio Grande do Sul. Revista Ciências Exatas e Naturais 2003 [cited 2019 May 17]; 5(1): 59-68. Available from: http://bit.ly/2W0t27R

Barreto PAB, Gama-Rodrigues EF, Gama-Rodrigues AC. Carbono das frações da matéria orgânica em solos sob plantações de eucalipto de diferentes idades. Scientia Forestalis 2014 [cited 2019 May 17]; 42(104): 571-580. Available from: http://bit.ly/2VDlDMd

Barreto PAB, Gama-Rodrigues EF, Gama-Rodrigues AC, Fontes AG, Polidoro JC, Moço MK et al. Distribution of oxidizable organic $\mathrm{C}$ fractions in soils under cacao agroforestry systems in Southern Bahia, Brazil. Agroforestry Systems 2011; 81(3): 213-220. 10.1007/ s10457-010-9300-4

Caldeira MVW, Saidelles FLF, Schumacher MV, Godinho TO. Biomassa de plantio de Acacia mearnsii De Wild., Rio Grande do Sul, Brasil. Scientia Forestalis 2011 [cited 2019 May 17]; 39(90): 133-141. Available from: http:// bit.ly/2JmkaDp

Caldeira MVW, Schumacher MV, Barichello LR, Vogel HLM. Determinação de carbono orgânico em povoamentos de Acacia mearnsii de Wild. plantados no Rio Grande do Sul. Revista Acadêmica Ciências Animal 2003; 1(2): 47-54. 10.7213/cienciaanimal.vli2.14913

Caldeira MVW, Soares RV, Watzlawick LF. Estimativa de biomassa em espécies arbóreas da floresta ombrófila
Mista Montana - General Carneiro-PR. Biomassa \& Energia 2004; 1(3): 291-310.

Castro EA. Biomass, nutrient pools and response to fire in the Brazilian Cerrado [thesis]. Corvallis: Oregon State University; 1996.

Chambers JQ, Santos J, Ribeiro RJ, Higuchi N. Tree damage, allometric relationships, and above ground net primary production in central Amazon forest. Forest Ecology and Management 2001; 152(1-3): 73-84. 10.1016/ S0378-1127(00)00591-0

Dalla-Corte AP, Sanquetta CR. Quantificação do estoque de carbono fixado em reflorestamentos de Pinus na área de domínio da Floresta Ombrófila Mista no Paraná. Cerne 2007; 13(1): 32-39.

Dallagnol FS, Mognon F, Sanquetta CR, Dalla-Corte AP. Teores de carbono de cinco espécies florestais e seus compartimentos. Floresta e Ambiente 2011; 18(4): 410-416. 10.4322/floram.2011.060

Eggleston S, Buendia L, Miwa K, Ngara T, Tanabe $\mathrm{K}$, editors. Guidelines for national greenhouse gas inventories: agriculture, forestry and other land use. Geneva: Intergovernmental Panel on Climate Change; 2006. v. 4.

Empresa Brasileira de Pesquisa Agropecuária - Embrapa. Manual de métodos de análise de solos. Rio de Janeiro: Serviço Nacional de Levantamento e Conservação de Solos; 1997.

Faria GE, Barros NF, Novais RF, Silva IR, Neves JCL. Carbono orgânico total e frações da matéria orgânica do solo em diferentes distâncias do tronco de eucalipto. Scientia Forestalis 2008; 36(80): 265-277. Available from: http://bit.ly/2Vt5Rib

Ferreira RLC, Lira MA Jr, Rocha MS, Santos MVF, Lira MA, Barreto LP. Deposição e acúmulo de matéria seca e nutrientes em serapilheira em um bosque de sabiá (Mimosa caesalpiniifolia Benth.). Revista Árvore 2007; 31(1): 7-12. 10.1590/S0100-67622007000100002

Franco AA, Dias LE, Faria SM, Campello EFC, Silva EMR. Uso de leguminosas florestais noduladas e micorrizadas como agentes de recuperação e manutenção da vida no solo: um modelo tecnológico. Oecologia Brasiliensis 1995; 1: 459-467.

Fraga MP, Barreto PAB, Paula A. Estimação de volume de Pterogyne nitens em plantio puro no sudoeste da Bahia. Pesquisa Florestal Brasileira 2014; 34(79): 207215. 10.4336/2014.pfb.34.79.703

Gama-Rodrigues AC, Barros NF, Mendonça ES. Alterações edáficas sob plantios puros e misto de espécies florestais nativas do sudeste da Bahia, Brasil. Revista Brasileira de Ciência do Solo 1999; 23(3): 581592. 10.1590/S0100-06831999000300011

Gama-Rodrigues AC, Gama-Rodrigues EF, Barros NF. Balanço de carbono e nutrientes em plantio puro e misto 
de espécies florestais nativas no Sudeste da Bahia. Revista Brasileira de Ciência do Solo 2008; 32(3): 1165-1179. 10.1590/S0100-06832008000300025

Gama-Rodrigues EF, Gama-Rodrigues AC, Nair PKR. Soil carbon sequestration in cacao agroforestry systems: a case study from Bahia, Brazil. In: Kumar BM, Nair PKR, editors. Carbon sequestration potential of agroforestry systems. New York: Springer; 2011. p. 85-99.

Gama-Rodrigues EF, Gama-Rodrigues AC, Paulino GM, Franco AA. Atributos químicos e microbianos de solos sob diferentes coberturas vegetais no norte do estado do Rio de Janeiro. Revista Brasileira de Ciência do Solo 2008; 32: 1521-1530. 10.1590/S0100-06832008000400016

Gatto A, Barros NF, Novais RF, Silva IR, Leite HG, Leite FP et al. Estoques de carbono no solo e na biomassa em plantações de eucalipto. Revista Brasileira de Ciência do Solo 2010; 34(4): 1069-1079. 10.1590/S010006832010000400007

Grimm R, Behrens T, Märker M, Elsenbeer H. Soil organic carbon concentrations and stocks on Barro Colorado Island: digital soil mapping using random forest analysis. Geoderma 2008; 146(1-2): 102-113. 10.1016/j. geoderma.2008.05.008

Higuchi N, Carvalho JA Jr. Fitomassa e conteúdo de carbono de espécies arbóreas da Amazônia. In: Anais do Seminário Emissão $\times$ Sequestro de CO2: Uma Nova Oportunidade de Negócios para o Brasil; 1994 May; Rio de Janeiro, RJ, Brasil. Rio de Janeiro: Companhia Vale do Rio Doce; 1994. p. 127-153.

Higuchi N, Chambers J, Santos J, Ribeiro RJ, Pinto ACM, Silva RP et al. Dinâmica e balanço do carbono da vegetação primária da Amazônia Central. Floresta 2004; 34(3): 295 304. 10.5380/rf.v34i3.2417

Hosokawa RT, Moura JB, Cunha US. Introdução ao manejo e economia de florestas. Curitiba: Editora UFPR; 1998.

Lal R. Soil carbon sequestration to mitigate climate change. Geoderma 2004; 123(1-2): 1-22. 10.1016/j. geoderma.2004.01.032

Lima MCD, Barreto-Garcia PAB, Sanquetta CR, Novaes AB, Melo LC. Biomass and carbon stock from Pinus caribaea var. hondurensis under homogenous stands in southwest Bahia, Brazil. Ciência Rural 2016; 46(6): 957962. 10.1590/0103-8478cr20150493

Lorenzi H. Árvores brasileiras: manual de cultivo de plantas arbóreas nativas do Brasil. Nova Odessa: Plantarum; 1998. v. 1 .

Machado SA, Figueiredo Filho A. Dendrometria. Curitiba: Editora dos Autores; 2003.

Masera OR, Garza-Caligaris JF, Kanninen M, Karjalainen T, Liski J, Nabuurs GJ et al. Modeling carbon sequestration in afforestation, agroforestry and forest management projects: the CO2 FIX V.2 approach.
Ecological Modeling 2003; 164(2-3): 177-199. 10.1016/ S0304-3800(02)00419-2

Melo LC, Sanquetta CR, Dalla-Corte AP, Hentz AMK. Estimativa de biomassa e carbono total para árvores de caixeta no Paraná. Pesquisa Florestal Brasileira 2014; 34(77): 21-29. 10.4336/2014.pfb.34.77.592

Morais VA, Santos CA, Mello JM, Dadid HC, Araújo EJG, Scolforo JRS. Spatial and vertical distribution of litter and belowground carbon in a Brazilian Cerrado vegetation. Cerne 2017; 23(1): 43-52. 10.1590/01047760201723012247

Morais VA, Scolforo JRS, Silva CA, Mello JM, Gomide LR, Oliveira AD. Carbon and biomass stocks in a fragment of cerradão in Minas Gerais state, Brazil. Cerne 2013; 19(2): 237-245. 10.1590/S0104-77602013000200007

Moura ON, Passos MAA, Ferreira RLC, Molica SG, Lira MA Jr, Lira MA et al. Distribuição de biomassa e nutrientes na parte aérea de Mimosa caesalpiniifolia Benth. Revista Árvore 2006; 30(6): 877-884. 10.1590/S010067622006000600002

Nair PKR, Nair VD, Kumar BM, Haile SG. Soil carbon sequestration in tropical agroforestry systems: a feasibility appraisal. Environmental Science \& Policy 2009; 12(8): 1099-1111. 10.1016/j.envsci.2009.01.010

Nelson BW, Mesquita R, Pereira JLG, Souza SGA, Batista GT, Couto LB. Allometric regressions for improved estimate of secondary forest biomass in the central Amazon. Forest Ecology and Management 1999; 117(13): 149-167. 10.1016/S0378-1127(98)00475-7

Neumann-Cosel L, Zimmermann B, Hall JS, Breugel MV, Elsenbeer $\mathrm{H}$. Soil carbon dynamics under young tropical secondary forests on former pastures: a case study from Panama. Forest Ecology and Management 2011; 261(10): 1625-1633. 10.1016/j.foreco.2010.07.023

Neves CMN, Silva MLN, Curi N, Macedo RLG, Tokura AM. Estoque de carbono em sistemas agrossilvopastoril, pastagem e eucalipto sob cultivo convencional na região Noroeste do estado de Minas Gerais. Ciência e Agrotecnologia 2004; 28(5): 1038-1046. 10.1590/S141370542004000500010

Pachauri RK, Meyer L, editors. Climate change 2014: synthesis report: contribution of working groups I, II and III to the Fifth Assessment Report of the Intergovernmental Panel on Climate Change. Geneva: IPCC; 2014.

Pires LA, Britez RM, Martel G, Pagano SN. Produção, acúmulo e decomposição da serapilheira em uma restinga da Ilha do Mel, Paranaguá, PR, Brasil. Acta Botanica Brasilica 2006; 20(1): 173-184. 10.1590/S010233062006000100016

Qiji W, Shixiong L, Zengchun J, Wenying W. Response of carbon and nitrogen content in plants and soils to vegetation cover change in alpine Kobresia meadow of the source region of Lantsang, Yellow and Yangtze Rivers. 
Acta Ecologica Sinica 2008; 28(3): 885-894. 10.1016/S18722032(08)60031-1

Saidelles FLF, Caldeira MVW, Schumacher MV, Balbinot R. Uso de equações para estimar carbono orgânico em plantações de Acacia mearnsii de Wild. no Rio Grande do Sul - Brasil. Revista Árvore 2009; 33(5): 907-915. 10.1590/ S0100-67622009000500013

Sallis SM, Assis MA, Mattos PP, Pião ACS. Estimating the aboveground biomass and wood volume of savanna woodlands in Brazil Pantanal wetlands based on allometric correlations. Forest Ecology and Management 2006; 228(13): 61-68. 10.1016/j.foreco.2006.02.025

Sanquetta CR, Dalla-Corte AP, Balbinot R, Leal MCBS, Ziliotto MA. Proposta metodológica para quantificação e monitoramento do carbono estocado em florestas plantadas. In: Sanquetta CR, Ziliotto MAB, editors. Carbono: ciência e mercado global. Curitiba: Ecoplan; 2004. p. 240-265.

Sanquetta CR, Watzlawick LF, Schumacher MV, Mello AA. Relações individuais de biomassa e conteúdo de carbono em plantações de Araucaria angustifolia e Pinus taeda no sul do estado do Paraná, Brasil. Revista Acadêmica Ciência Animal 2003; 1(3): 33-40. 10.7213/cienciaanimal. v1i3.14937

Santos HG, Jacomine PKT, Anjos LHC, Oliveira VA, Lumbreras JF, Coelho MR et al. Sistema brasileiro de classificação de solos. 2nd ed. Rio de Janeiro: Embrapa Solos; 2006.

Schneider PR, Finger CAG, Sobrinho VG, Schneider PSP. Determinação indireta do estoque de biomassa e carbono em povoamentos de acácia-negra (Acacia mearnsii De Wild.). Ciência Florestal 2005; 15(4): 391402. 10.5902/198050981876

Schumacher MV, Brun EJ, Hernandes JI, König FG. Produção de serapilheira em uma floresta de Araucaria angustifolia (Bertol.) Kuntze no município de Pinhal Grande-RS. Revista Árvore 2004; 28(1): 29-37. 10.1590/ S0100-67622004000100005

Scolforo HF, Scolforo JRS, Mello JM, Mello CR, Morais VA. Spatial interpolators for improving the mapping of carbon stock of the arboreal vegetation in Brazilian biomes of Atlantic forest and Savanna. Forest Ecology and Management 2016; 376: 24-35. 10.1016/j. foreco.2016.05.047

Silva GTA, Queiroz ROM, Nóbrega PO, Campello EFC, Resende AS. Caracterização dos teores de nitrogênio, polifenol e relação C:N no tecido foliar de diferentes espécies vegetais em um sistema silvipastoril. In: Anais da 14a Jornada Científica da Universidade Federal Rural do Rio de Janeiro; 2004; Seropédica, Rio de Janeiro, Brasil. Seropédica: Universidade Federal Rural do Rio de Janeiro; 2004. p. 55-59.

Silva KE, Souza CR, Azevedo CP, Rossi LMB. Dinâmica florestal, estoque de carbono e fitossociologia de uma floresta densa de terra-firme na Amazônia Central. Scientia Forestalis 2015 [cited 2019 May 17]; 43(105): 193-201. Available from: http://bit.ly/2Hn4tK0

Swift MJ, Heal OW, Anderson JM. Decomposition in terrestrial ecosystems. Oxford: Blackwell; 1979.

Thompson RM. Estimativas de volume, biomassa e carbono para o carvoeiro (Sclerolobium paniculatum Vog. var. subvelutinum Benth) [thesis]. Brasília, DF: Universidade de Brasília; 2009.

Torres CMME, Jacovine LAG, Soares CPB, Oliveira Neto SN, Santos RD, Castro Neto F. Quantificação de biomassa e estocagem de carbono em uma floresta estacional semidecidual, no parque tecnológico de Viçosa, MG. Revista Árvore 2013; 37(4): 647-655. 10.1590/S010067622013000400008

Vieira G, Sanquetta CR, Barbeiro LSS. Estoque individual de biomassa e carbono em Nectandra grandiflora Nees (Canela-amarela). Revista Floresta 2009; 39(3): 547-554. 10.5380/rf.v39i3.15354

Watzlawick LF, Caldeira MVW, Godinho TO, Balbinot $\mathrm{R}$, Trautenmüller JW. Aboveground stock of biomass and organic carbon in stands of Pinus taeda L. Cerne 2013; 19(3): 509-515. 10.1590/S0104-77602013000300019

Watzlawick LF, Caldeira MVW, Viera M, Schumacher MV, Godinho TO, Balbinot R. Estoque de biomassa e carbono na floresta ombrófila mista Montana Paraná. Scientia Forestalis 2012 [cited 2019 May 17]; 40(95): 353 362. Available from: http://bit.ly/2w5358g

Watzlawick LF, Kirchner FF, Sanquetta CR, Schumacher MV. Fixação de carbono em floresta ombrófila mista em diferentes estágios de regeneração. In: Sanquetta CR, Watzlawick LF, Balbinot R, Ziliotto MAB, Gomes FS et al., editors. As florestas e o carbono. Curitiba: Editora dos Autores; 2002. p. 153-173.

Watzlawick LF, Sanquetta CR, Arce JE, Balbinot R. Quantificação de biomassa total e carbono orgânico em povoamentos de Araucaria angustifolia (Bertol.) Kuntze no sul do estado do Paraná, Brasil. Revista Acadêmica Ciência Animal 2003; 1(2): 63-68. 10.7213/cienciaanimal. v1i2.14919 